\title{
AUDIOVISUAL
}

\section{VELHO CHICO: UMA JORNADA INTELECTUAL RUMO A UMA POÉTICA MESTIÇA}

\author{
VELHO CHICO: A SEMIOTIC-SYSTEMIC ANALYSIS \\ VELHO CHICO: UN ANÁLISIS SEMIÓTICO-SISTÉMICO \\ Marcelo Moreira Santos'
}

RESUMO: este artigo pretende analisar a poética audiovisual articulada pelo diretor Luiz Fernando Carvalho na recente telenovela Velho Chico (2016). Compreendendo poética a partir de Bordwell (2008) que a define como um ramo de estudos do cinema voltado a manufatura audiovisual, isto é, a um entendimento sobre o processo de criação, produção e efeito. Entretanto, diferentemente de Bordwell cuja matriz conceitual gira em torno do cognitivismo, adotamos como ponto de partida as teorias sistêmicas de Edgar Morin, Mário Bunge, llya Prigogine e Jorge Vieira. Dessa forma, o texto centra-se, em primeiro lugar, no esclarecimento da organização sistêmica que molda a poética do audiovisual no que tange ao seu caráter colaborativo, isto é, vários agentes semióticos contribuindo na manufatura da obra, no caso a telenovela. Em segundo, é observado sua complexidade semântica com seus encontros e sincretismos sígnicos advindos de várias influências culturais e estéticas. Para em seguida, o artigo salientar que Velho Chico é, ao mesmo tempo, um ponto de chegada e um ponto de partida para círculo-evoluções sígnicas, isto é, para outros rincões sígnicos, fluindo, desaguando e se ramificando por outras vertentes, criando uma linguagem sinérgica e mestiça própria àquele universo ficcional. Por fim, o texto conclui que Velho Chico é uma jornada intelectual do diretor Luiz Fernando Carvalho na busca de um novo paradigma, uma poética audiovisual que acolha seus ideais estéticos: uno, múltiplo, complexo.

Palavras-Chave: Velho Chico. Poética do Audiovisual. Análise Semiótico-Sistêmica. 
ABSTRACT: this article aims to analyze the audiovisual poetics articulated by director Luiz Fernando Carvalho in the recent soap opera Velho Chico (2016). Understanding poetics from Bordwell (2008) who defines it as a branch of film studies focused on audiovisual manufacturing, that is, an understanding of the process of creation, production and effect. However, unlike Bordwell whose conceptual matrix revolves around cognitivism, we take as a starting point the systemic theories of Edgar Morin, Mario Bunge, llya Prigogine and Jorge Vieira. Thus, the text focuses, firstly, on the clarification of the systemic organization that shapes the audiovisual poetics in terms of its collaborative character, that is, several semiotic agents contributing to the manufacture of the work, in this case the soap opera. Second, its semantic complexity is observed with its sign encounters and syncretisms arising from various cultural and aesthetic influences. Next, the article points out that Old Chico is both a point of arrival and a starting point for signic circle-evolutions, that is, for other signic corners, flowing, draining, and branching into other strands, creating a synergistic and mestizo language proper to that fictional universe. Finally, the text concludes that Velho Chico is an intellectual journey of director Luiz Fernando Carvalho in search of a new paradigm, an audiovisual poetic that embraces its aesthetic ideals: unic, multiple, complex.

KeyWords: Velho Chico. Poetics of Audiovisual. Semiotic-Systemic Analysis.

RESUMEN: este artículo tiene como objetivo analizar la poética audiovisual articulada por el director Luiz Fernando Carvalho en la reciente telenovela Velho Chico (2016). Comprensión de la poética de Bordwell (2008), quien la define como una rama de los estudios cinematográficos centrados en la fabricación audiovisual, es decir, una comprensión del proceso de creación, producción y efecto. Sin embargo, a diferencia de Bordwell, cuya matriz conceptual gira en torno al cognitivismo, tomamos como punto de partida las teorías sistémicas de Edgar Morin, Mario Bunge, llya Prigogine y Jorge Vieira. Así, el texto se centra, en primer lugar, en la clarificación de la organización sistémica que da forma a la poética audiovisual en términos de su carácter colaborativo, es decir, varios agentes semióticos que contribuyen a la fabricación de la obra, en este caso la telenovela. En segundo lugar, se observa su complejidad semántica con sus encuentros con signos y sincretismos derivados de diversas influencias culturales y estéticas. A continuación, el artículo señala que Old Chico es a la vez un punto de llegada y un punto de partida para las evoluciones de círculos significativos, es decir, para otras esquinas significativas, que fluyen, fluyen y se ramifican en otros hilos, creando un lenguaje sinérgico y mestizo propio de ese universo ficticio. Finalmente, el texto concluye que Velho Chico es un viaje intelectual del director Luiz Fernando Carvalho en busca de un nuevo paradigma, una poética audiovisual que abraza sus ideales estéticos: unico, múltiple, complejo.

Palabras-Clave: Velho Chico. Poética audiovisual. Análisis semiótico-sistémico. 


\section{Introdução}

Era o começo do segundo semestre de 2007 quando houve a exibição da microssérie A Pedra do Reino (2007), uma adaptação do livro de Ariano Suassuna em uma sala de cinema no Shopping Frei Caneca, São Paulo. O evento, além de exibir os três primeiros episódios da microssérie, também reservou um espaço para um "bate-papo" com o diretor Luiz Fernando Carvalho e sua equipe.

O início desse diálogo com o público presente envolveu uma descrição de como se desenvolveu a realização dessa tradução intersemiótica entre literatura e televisão, ressaltando as opções que o próprio diretor fez em relação a essa mudança de meio de comunicação. Foi nesse momento que Luiz Fernando revelou que não estava procurando "fazer televisão", mas buscava uma "outra coisa", que naquele momento não sabia muito bem o que era. Olhando para um dos seus mais recentes trabalhos, Velho Chico (2016), esse ideal estético, outrora imaterial e platônico, parece ter se concretizado e colocado novos parâmetros estéticos e de linguagem a sua própria poética.

Esse laboratório de experiências televisivas vem sendo sua marca autoral, desde a microssérie Hoje é dia de Maria (2005), passando pela própria A Pedra do Reino, e encontrando no consagrado autor Benedito Ruy Barbosa um importante parceiro de experimentações, algo já visto na telenovela Meu Pedacinho de Chão (2014) e neste mais recente Velho Chico. Entretanto, tal parceria não é nova já que ambos trabalharam juntos em Renascer (1993) e em O Rei do Gado (1996), a novidade agora é a maneira como é construída e urdida a linguagem pela qual é contada a história.

Velho Chico exibida pela Rede Globo de Televisão em 2016 é uma telenovela que trouxe algumas peculiaridades e paradoxos importantes em termos de linguagem televisiva e em termos de camadas de sentido, não fugindo da métrica consagrada ao folhetim, mas o transformando. Transformar tem que ser observado aqui não no sentido de revolucionar o gênero, e sim de trilhar outro caminho possível, pegando elementos clássicos já convencionados e enxertando rupturas, contradições e realinhamentos em prol de uma consciente experimentação: imersa no gênero, o reconfigurando de dentro para fora.

O enredo de Velho Chico flerta com os cânones de Romeu e Julieta, a famosa obra do dramaturgo inglês William Shakespeare, e de maneira similar a história apresenta um amor proibido entre filhos de duas famílias rivais que passam boa parte da trama tentando lidar: de um lado com o dever em relação a família e de outro com o desejo de consumar suas paixões. A telenovela tem como cenário uma cidade no sertão nordestino brasileiro às margens do Rio São Francisco e 
traz como ponto de inflexão os inter-relacionamentos entre: a) erudito e popular; b) discurso politizado e ecologia; c) realismo e misticismo; c) teatro e cinema; $d$ ) literatura e televisão; integrando-os em um grande jogo de linguagens.

Avesso às delimitações fronteiriças, a telenovela traça um caminho de uma constante interação, recursiva e retroativa, entre esses nichos, forjando uma estética polimorfa que só se consolida pela diversidade e pluralidade de seus encontros. Fugindo do pastiche, algo notório no seu antecessor Meu Pedacinho de Chão, e das remixagens da cultura pop, Velho Chico faz eco ao Tropicalismo, e lá onde as "franjas desse mar" - leia-se caldo cultural com intersecções regionais, nacionais e internacionais - arrebentam, transbordam e fazem redemoinhos é que se insere seu horizonte semiótico.

Nesse ambiente caótico, autofágico, de gênesis, apto tanto à decomposição/ destruição quanto à criação, é que se tece o espaço necessário ao prefixo "re": reformulação, recomposição, reconfiguração. Tal movimento prepara o solo para os rearranjos semânticos prenhes de mutações e mestiçagens corroborando na formação de um paradoxo que desagua na singularidade de seu sincretismo: único e múltiplo. Uma obra com múltiplas interfaces, ou melhor, dizendo, um "rio" - o velho chico - com diversos afluentes e ramificações.

\section{Sobre Aprendizagens, Enraizamentos e Bifurcações}

Velho Chico não é uma experiência isolada, seu enraizamento semiótico e sistêmico advém de outras obras anteriores - Renascer, Rei do Gado, Hoje é dia de Maria, A Pedra do Reino, Meu Pedacinho de Chão etc., - e provavelmente terá ressonância em outras que a sucederão para ambos os autores. Este fluxo dos signos que lhe sustenta e confere coesão semântica tem como eixo gravitacional, ou pivô de encontros e inter-relacionamentos, a associação e complementação de seu autor e de seu diretor-geral, respectivamente, Benedito Ruy Barbosa e Luiz Fernando Carvalho. Aliás, é a partir dessa nucleação que se desenvolve a organização ativa do sistema e que lhe confere autonomia, ambiente e permanência (VIEIRA, 2008, p. 32-35).

Retirar esta telenovela de seu fluxo espaço-temporal - leia-se semiose - é perder de vista a matriz processual de sua eco-organização (MORIN, 2005) É nítido que as interações entre as linguagens e discursos ocorrem de maneira dinâmica operando flutuações, confluências e dispersões ao longo dos capítulos. Entretanto, organizar este jogo sistêmico de maneira a promover coerência e coesão semântica demanda certa experiência de quem o articula. Esta experiência - aprendizagem/mediação - advém de outros trabalhos/obras a esta 
entrelaçada, ao ponto de se observar certos paralelos, referências e conexões entre este título com os seus antecessores.

Primeiramente, é preciso compreender que as interações estéticas e de linguagem por si só não formam um sistema, isto é, enxertar elementos distintos e variados não fazem com que uma organização surja e se estabeleça, é preciso que haja algo atuando de maneira que integre o diverso no uno(MORIN, 2005). Este "algo" - platônico e imaterial - aparece e se desenvolve na medida em que os eventos e interações que outrora eram aleatórios e dispersos começam a formar rincões onde impera ordem, isto é, o sistema faz da desordem um elemento basilar para a ordem, não a exclui, mas a supera, aprende, assimila o caótico e o canaliza rumo à atividade constante: criativo, influente, interativo e integrado (MORIN, 2008a).

A organização - método criativo (SANTOS, 2015) - floresce ao longo desse processo, ela é fruto da experiência, da mediação, entre as partes e o todo, e entre o todo às partes. Não é um princípio de harmonia, ao contrário. Essa visão holística é colocada em xeque aqui, pois tal princípio simplifica o sistema, cala as diferenças internas - antagonismos, contradições, dispersões - e principalmente o processo de entropia. Aliás, o conceito de organização fica mais rico quando o compreendemos a partir desse ponto de vista dinâmico, dissipativo (PRIGOGINE, 2002, p. 21).

No caso de Velho Chico o desafio não foi só organizar os encontros, que por si só já é complexo, mas superar uma organização já engessada pelo tempo: a própria padronização da telenovela brasileira. É por isso que não poderia aqui observá-la de maneira separada, pois essa ruptura - bifurcação (PROGOGINE, 2002, p. 24) - começa lá em 2005 com Hoje é Dia de Maria (ver BRITTOS; SIMOES, 2006, p. 47-70) e flui de maneira espiralada por outros títulos até chegar em 2016.

Nasce como uma pequena experiência laboratorial, uma microssérie. Reservada a um espaço-tempo exprimido de uma grade de programação consolidada, petrificada. E é nesse solo árido das convenções enrijecidas que brota a semente que um dia gerará Velho Chico. Surge como elemento aleatório no contexto televisivo que com o passar do tempo escoa por experiências, aprendizagens, metodologias, até formar o ambiente profícuo a sua veiculação em um horário denominado "nobre". Assim, é a experiência/aprendizagem de outras obras antecessoras que permitiu sua organização complexa, seu sistema. Autonomia (VIEIRA, 2008, p. 35) requer, portanto, memória sistêmica, isto é, know-how para lidar com os desafios que a realidade impõe tanto em questão de construção de linguagem, quanto de formação de uma equipe especializada para desempenhar suas funções e competências, quanto também de desenvolvimento de um contexto propício ao acolhimento e receptividade à obra. 
Híbrida, mestiça, Velho Chico consegue dosar os excessos laboratoriais de $2005 \mathrm{e}$ a extravagância de Meu Pedacinho... em conjunto às convenções melodramáticas e épicas abordadas e estabelecidas em Renascer e O Rei do Gado. Assim, encontrando um meio termo - aqui chamada de bifurcação - entre as duas vertentes, a telenovela circula e se nutre de ambas as experiências, num claro processo de simbiose entre os seus dois autores principais. Por certo, um influi sobre o trabalho criativo do outro em uma dialogia ecodependente tecendo e consolidando sua nucleação.

Por outro lado, é essa nucleação em torno dos autores que move a organização ativa (MORIN, 2008a), é, portanto, o fechamento do sistema, porém não total ao ambiente em que está imerso, pois essa associação nucleadora, para ter autonomia, alimenta-se de saberes - memória sistêmica de elementos pregressos - aos quais está umbilicalmente conectada. Dessa forma, é a partir dessa nucleação que se projeta - in futuro - os níveis e camadas de inter-relações semióticas e sistêmicas pelos quais Velho Chico se debruça, escoa e desagua.

\section{Sobre Complementaridades, Nucleações e Unidades Complexas}

Borwell (2008) observa que o termo poética está atrelado ao fazer, mas não é o fazer apenas do ato, mas ao fazer artístico, um aprimoramento da arte. Ele aponta que toda arte tem seus princípios gerais, suas convenções, e que a análise de uma poética não está baseada numa obra em particular, mas, ao contrário, naquilo que é geral e inerente a todas as obras daquele ramo artístico em foco. Assim, é preciso olhar a poética como um parâmetro de análise e a partir deste parâmetro compreender a especificidade do artista e de sua obra.

A telenovela, assim como uma produção cinematográfica, implica a integração e interação de um conjunto de agentes especializados em áreas específicas. O que se constata é que essas interações (MORIN, 2008a) que compõem e moldam a realização de uma telenovela configuram-se como sistêmicas, isto é, há um conjunto de agentes semióticos com funções específicas que interagem e se integram na realização da obra.

Esta interação entre agentes especializados e sua integração forma uma organização ativa cuja matriz processual é forjada pelo jogo multiforme e relativo entre diversidade, variedade, antagonismo, desvio, ruptura, equilíbrio, ordem e desordem. Assim, uma telenovela não é assinada apenas pelo seu núcleo de autores, mas por um conjunto de agentes, e tal dinâmica opera em torno de concessões, cooperações e associações entre as competências participantes. De fato, essa unidade complexa depende de uma eco-organização (MORIN, 2005), cuja lógica gira em torno de processos temporais, que por sua vez comportam transformações, flutuações e intersemioses. 
O que se observa é que há, em graus maiores ou menores, o risco de essa combinação entre agentes e especialidades entrar em processo de entropia (MORIN, 2008a), perdendo a coesão sintática e a coerência semântica, prejudicando as interfaces e intercâmbios intersemióticos entre suas várias camadas de significação. Elas são cunhadas e entrelaçadas pela integralidade e organização da direção de fotografia, direção de arte, figurino, cenografia, trilha sonora, roteiro, direção, edição de imagens etc., dentro de um todo complexo. Assim, a riqueza organizacional de um sistema é medida pela sua diversidade e variedade, pois sua lógica é pautada pela transformação, geração e produção, ou como Morin destaca: as interações e associações - entre essas áreas distintas inerentes ao processo - "se entreproduzem" (MORIN, 2008a, p. 202).

No audiovisual, cada agente, em sua especialidade, é responsável por um fragmento sígnico que passa pelo crivo de sua criação, desenvolvimento e produção. Esse fragmento tem que: a) conectar-se; b) traçar relações; c) estruturar-se, isto é, estabelecer e fortalecer essas relações intersemióticas - de troca - ao longo do período de realização da telenovela; d) integrar-se a outras partes sígnicas em um processo de complementaridade; e) cumprir uma função, visando uma cooperação mútua e interdependente; f) e corporificar-se em uma organização (ou organicidade) coesa o suficiente que consiga desenvolver uma regularidade pragmática durante todo o processo de realização da obra. De fato, uma fotografia, um figurino, uma direção de arte, por exemplo, integram-se e tomam corpo pela complexidade com que dialogam entre si, pelas interfaces e intercâmbios sígnicos que são capazes de realizar e, principalmente, manter e entreproduzir, portanto, transformar (MORIN, 2008a, p. 148).

No caso de Velho Chico, o que faz essa multiplicidade de agentes - roteiristas colaboradores, diretores, diretores de arte, figurinistas, cenógrafos, diretores de fotografia, editores de imagens, atores/atrizes, músicos compositores, editores de áudio etc. - funcionarem em uma unidade complexa e interatuante é exatamente a associação nucleadora entre o autor e o diretor-geral da telenovela. Se por um lado o roteiro de Benedito Ruy Barbosa serve de guia ou base de consulta constante a todos os subsistemas envolvidos, por outro é Luiz Fernando Carvalho que organiza as performances, as estratégias de ação, mediando as competências dos profissionais envolvidos, transformando a diversidade em uma unidade complexa. Assim, a nucleação do sistema - o que implica dizer difusão de informação e a elaboração/execução de método/estratégia de performances - favorece o florescimento destes agentes como artistas e coautores, isto é, promove a diversidade, provê a interdependência e permite o intercâmbio entre as partes e o todo neste policircuito recursivo retroativo. 
Dessa forma, o roteiro confere informação, isto é, assinala o que cada um tem que executar ao longo do desenvolvimento da obra, pois se torna, ao mesmo tempo, guardião e fonte da ideia matricial da obra (MORIN, 2008a), seu argumento. De fato, esse papel de fonte - estocagem - de informação é que faz com que os agentes semióticos envolvidos conheçam, entendam e desenvolvam suas especialidades (MORIN, 2008a).

Aliás, é a partir da transmissão dessa informação - seja contida no roteiro, e/ou ainda difundida pelo diretor-geral nas reuniões com a equipe - que as estratégias de realização da telenovela são traçadas. Assim, por um lado, forma-se um centro de controle/comando - nucleação - e, de outro, um caráter "programático" responsável por instruir uma pluralidade de performances que se desenvolvem e se modificam em função das circunstâncias entrópicas encontradas ao longo de sua produção. Ambos os processos têm o intuito de se atingirem finalidades específicas projetadas para complementar e integrar tais agentes/artistas/profissionais a um todo (MORIN, 2008a) no caso, a telenovela.

Logo, esse fluxo de informação transforma-se em fator fundamental para se evitar o processo de degenerescência que ronda todo sistema (MORIN, 2005), pois compete à qualidade, e não à quantidade com que estas informações são difundidas, o papel de diminuir os desperdícios, os erros de percurso e os colapsos. Aliás, a própria qualidade com que a informação foi trabalhada na fase de desenvolvimento do roteiro, entre autor e seus colaboradores, influi e aparece nesse processo de difusão, pois, com tais dados "em mãos", o diretor de arte esboça a visualidade da telenovela, o diretor de fotografia compõe o tipo de iluminação, enquadramentos e lentes empregados nas cenas, o figurinista traça o estilo de vestuário dos personagens, o cenógrafo rascunha e seleciona os cenários e os objetos de cena a serem empregados nas gravações, os atores e atrizes exploram e criam suas interpretações, e os diretores organizam e regem o desenvolvimento das cenas e capítulos.

Já o papel de guardião - de informação - refere-se à função de regulação do policircuito, isto é, o de reiterar, repetir, regenerar o que a gerou: a ideia matricial e/ou generativa (MORIN, 2005), o DNA da história. O conceito de regulação implica neutralizar as perturbações e desvios, ou seja, saber conviver, explorar e assimilar os processos entrópicos - adversidades diversas - e tecer uma regularidade nas inter-relações, associações, cooperações, complementaridades e intersemioses ao longo do processo de realização da telenovela.

Daí a importância da memória sistêmica, do know how construído e entrelaçado por outros títulos pregressos, pois esse processo de adaptação (MORIN, 2005) é fundamental para a liberdade criativa pretendida. O novo, outrora esporádico, 
para sobreviver tem que se adaptar ao mesmo tempo em que adapta o ambiente. A liberdade - no caso a criativa - é uma singela confluência de condições ímpares concorrentes, antagônicas, complementares - para que esta possa se estabelecer e florescer. Não podemos perder de vista as demandas econômicas implicadas à faixa mais nobre da televisão brasileira, pois não haveria, portanto, autonomia, ambiente e, muito menos, permanência - já que uma telenovela fica em torno de seis a sete meses "no ar" - se não houvesse respaldo em experiências anteriores.

\section{Sobre Flutuações, Entreveros e Redemoinhos}

A complexidade de Velho Chico não está apenas em sua ontologia sistêmica vinculada à sua produção e desenvolvimento, ela aparece em sua linguagem sincrética permeada de encontros sígnicos aberto às flutuações, realinhamentos e desdobramentos que escoaram ao longo de seus setecentos e setenta e três capítulos. Assim, personagens e elementos denominados secundários surgiam à superfície com monólogos ou ainda com performances que apontavam para outras obras e linguagens, como teatro, literatura, música, fotografia, manifestações culturais regionais e afins, aquém do enredo principal. Permitindo, como consequência, que o horizonte semiótico da telenovela criasse integrações diversas, isto é, uma rede de correlações variadas promovendo múltiplas abordagens, ênfases e pontos de aderência à história criada por ambos os autores.

Aliás, um exemplo desse processo dinâmico é o caso da personagem Luzia (Figura 1) interpretada por Lucy Alves. "Pinçada" do fluxo contínuo da telenovela, suas performances embaladas ao som do toque da sanfona e tendo ventanias ao seu redor representavam a tempestade interna vivida pela personagem que não aceitava o amor de Santo (Domingos Montagner), seu marido, com Tereza (Camila Pitanga).

Como uma entidade das matas sertanejas, Luzia personificava essas figuras do imaginário popular que fazem rebuliço e se escondem ou que se movem em meio aos redemoinhos, rebojos e turbilhões trazendo consigo ainda a sanfona, instrumento emblemático ao povo nordestino, usada tanto para cantar suas alegrias quanto suas tristezas. Nesse processo, Luzia era um canal pela qual esses afluentes sertanejos mítico-imaginários desembocavam à história da telenovela. De fato, esta personagem criava, tecia e integrava esses eixos semânticos mitológicos ao curso da trama da telenovela. 
Figura 1 - Imaginário Popular

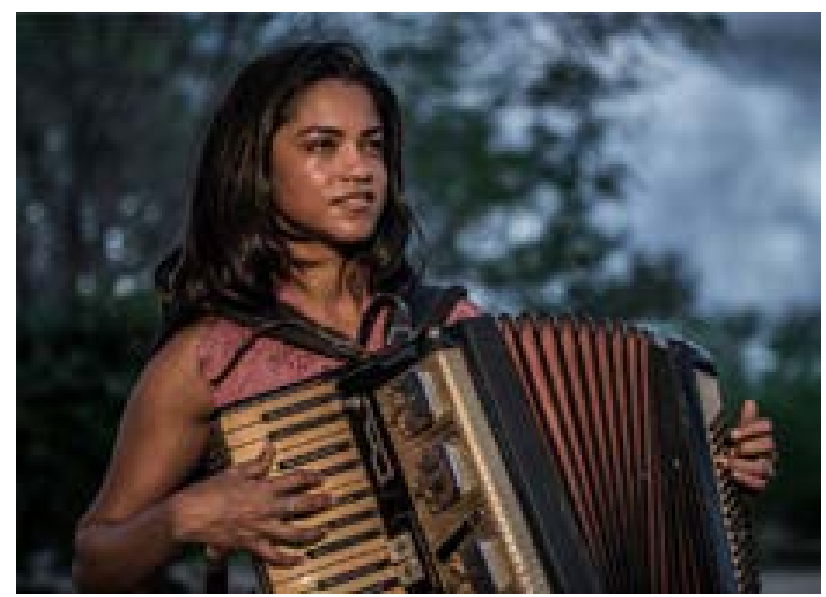

Fonte: gshow.com.br.

Esse rico ambiente mítico-imaginário é ainda explorado de outras maneiras ao longo da telenovela. Algo comum à sua narrativa era assistir diversos personagens com suas rezas e orações diante de oratórios (Figura 2). Esses ritos trafegavam aqui e ali em diferentes casas e na própria igreja da cidade, formavam, portanto, uma camada secundária e basilar às narrativas e aos personagens. Sobretudo, conferia-Ihe uma paisagem simbólica por onde a história transcorria. Entretanto, ao longo de uma cena específica, a da embosca do protagonista Santo e seu irmão Bento (Irandhir Santos), o que se observa é que tais rezas e ritos não são apenas um costume sem razão de ser, ao contrário.

Figura 2 - Oratórios

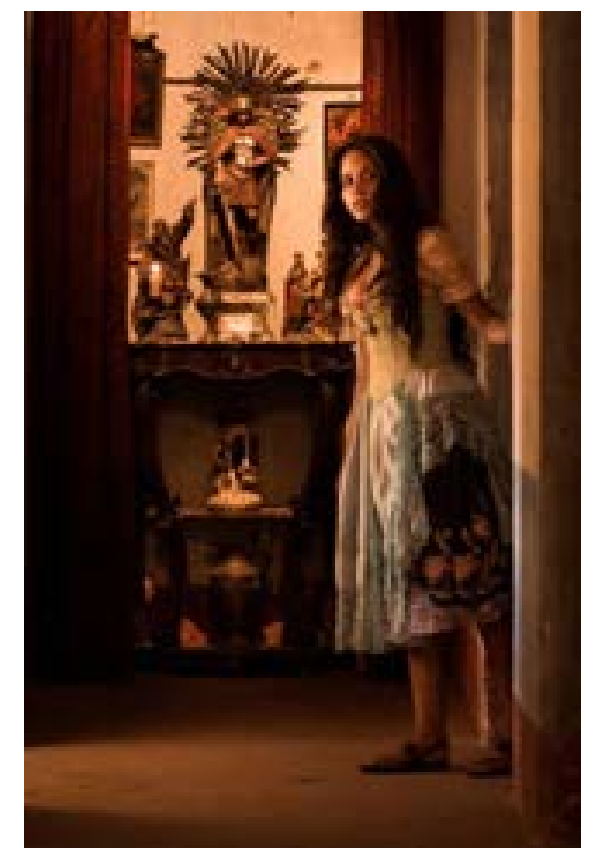

Fonte: extra.globo.com. 
Na cena, enquanto os jagunços do Coronel Saruê (Antônio Fagundes) atiravam em direção a Santo e a seu irmão Bento, eles, além de responderem atirando de volta, recitavam uma oração do santo protetor da sua família, São Jorge. ${ }^{2}$ Essa "armadura de Deus" (Efésios, 6-13) fechava os corpos de ambos os personagens afugentando os pistoleiros, que sem entender o que estava acontecendo correm, apavorados, deixando-os para trás (Figura 3).

Figura 3 - Corpo Fechado

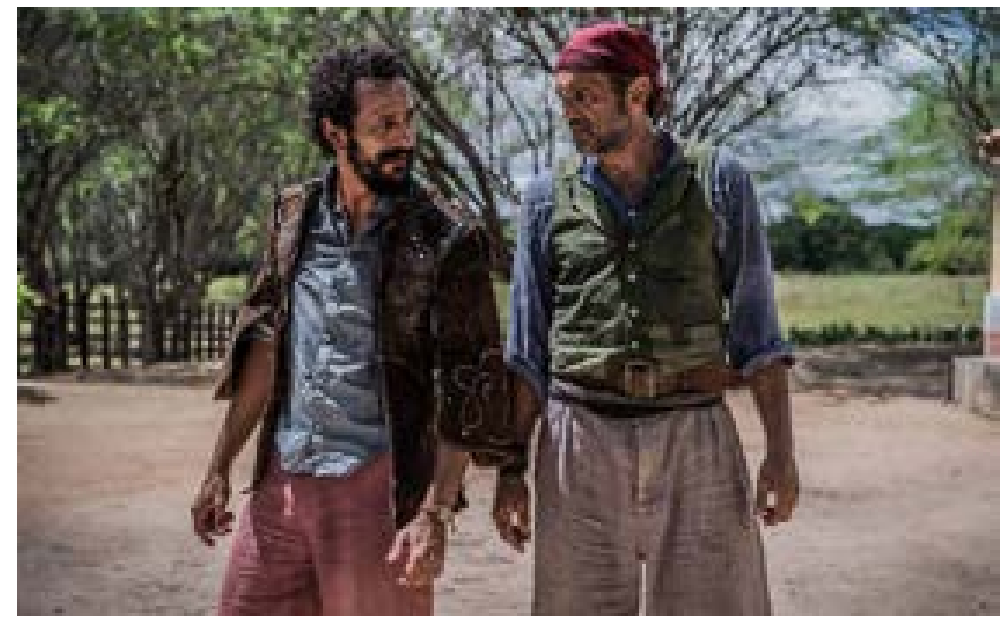

Fonte: tvefamosos.uol.com.br/blog/mauriciostycer.

De fato, esta cena conecta e dá vazão às crenças e ao imaginário popular vinculado à realidade do cotidiano sertanejo. Por certo, o sertanejo não isola a sua crença de sua vida prática, ele vive uma unidualidade (MORIN, 2008b), isto é, o imaginário-simbólico-mítico está integrado às demandas da vida diária como a lida com o gado, a roça, a colheita etc., aquilo que o autor denomina como a vida empírica-lógica-racional (MORIN, 2008b). Uma alimenta a outra.

Da mesma forma, a narrativa da telenovela caminha pela mesma 'toada', as crendices e mitos ora aparecem como coadjuvantes, ora são enaltecidas, porém ambas se nutrem, estão integradas, circulam em espiral. Este movimento dinâmico enriquece o ambiente semiótico criado pela obra, pois joga o telespectador em meio a uma circularidade de elementos semânticos - míticos, simbólicos, empíricos e racionais - concorrentes e complementares, ampliando a experiência com a realidade ficcional em curso, criando um emaranhado de camadas de significação, recursivas (que retornam) e retroativas (e se expandem).

2 Disponível em: https://www.youtube.com/watch?v=Z1WzCe7ls24. 
Assim, se por um lado a trama principal que envolvia o casal Santo e Tereza era o que ancorava a história, isto é, dava-Ihe um parâmetro narrativo similar ao leito de um rio, por outro, esses outros elementos dramáticos secundários é que permitiam o jogo de linguagens e suas múltiplas interfaces.

Portanto, Velho Chico trafegou exatamente nesse sentido: por meio de uma variabilidade de camadas de significação, ou feixes semióticos, é que se projetou sua interação lúdica com o telespectador. Por outro lado, colocar tais dimensões de informação e correlações diversas não favorece uma "leitura" massificada e ordeira da telenovela, tornando sua mediação relativa e dispersa, dependente da bagagem cultural de cada um de seus telespectadores.

Isso, em termos de comunicação de massa aos moldes do cânone ShannonWeaver (emissor - receptor) avesso aos ruídos e aos desvios de interpretação da mensagem enviada e codificada, seria um índice de incoerência de sentido. Tal incoerência pode ser observada em uma cena de delírio e loucura do Coronel Saruê, personagem interpretado por Antônio Fagundes.

Ao final da novela, este personagem inicia uma jornada de redenção, perdendo seus status de vilão na trama principal, e se encaminhando em direção ao arquétipo do vilão arrependido de seus atos, humanizando-o. A cena em si gira em torno de sua busca pelo filho desaparecido e é emblemática por ser uma releitura de um famoso trecho do livro de Miguel de Cervantes, Dom Quixote de la Mancha, em que Dom Quixote enfrenta os gigantes/moinhos de vento junto de seu fiel cavalo Rocinante. No caso do Coronel, há um embate com os "moinhos de vento" modernos encontrados nos sertões e litorais do Nordeste (Figura 4).

Figura 4 - Dom Quixote

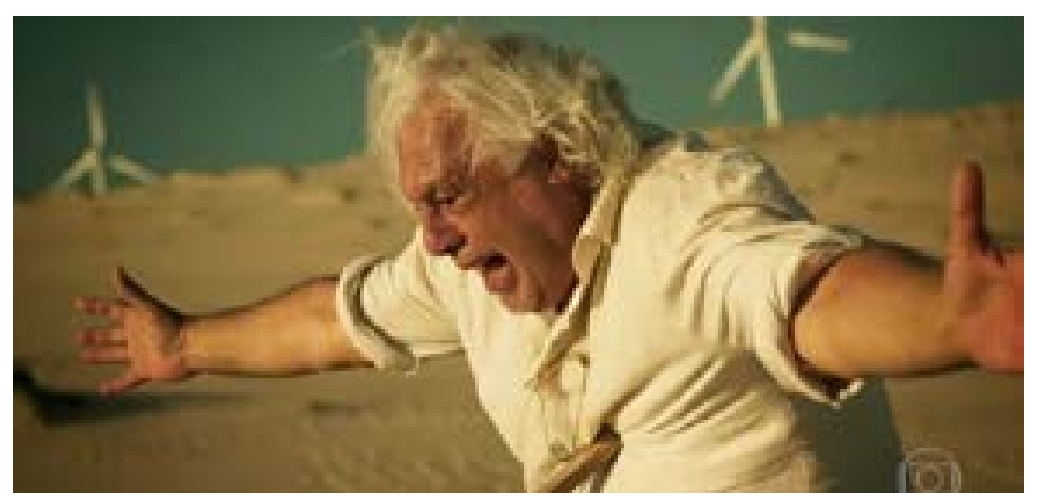

Fonte: figurasdatv.uol.com.br.

Ocorre que, em nenhum momento, é citada a obra de Cervantes ao longo da cena e só quem tem uma vivência de leitura do autor espanhol e/ou de suas 
adaptações em teatro e/ou cinema é que poderia entender a intertextualidade em curso. Aos telespectadores que nunca leram ou viram Cervantes, a cena mostra apenas a loucura do Coronel, a informação em si é transmitida, mas para os que já tiveram a experiência lúdica com a obra original, ela torna-se muito mais do que a loucura deste personagem, transporta, traz à memória as experiências com a leitura das aventuras de Dom Quixote.

Portanto, a reencenação diante dos moinhos de vento em Velho Chico cria, tece e deflagra certas integrações semânticas afetivas aquém de sua narrativa, ao ponto de se ter de criar mapas mentais para se poder mediar, com a riqueza que lhe é devida, a cena em si. Por certo, somos deslocados para outras vivências lúdicas aquém de sua origem. Dessa maneira, para entender as influências intersimbólicas (VIEIRA, 2007, p. 58) em curso, pressupõe do telespectador uma memória sistêmica em consonância ao que lhe é apresentado.

Assim sendo, dependendo do telespectador, uma mesma cena tem projeções, interpretações e leituras diferentes. Aliás, tal fato não se restringe a esta reencenação apenas e nem a uma obra ou linguagem. Por certo, ao longo de toda a temporalidade da telenovela, essas integrações semânticas afluem e abundam de várias formas, tecendo uma rede de influências intersimbólicas inter-relacionáveis como se tais complementações fossem necessárias à compreensão da narrativa da telenovela como um todo, isto é, como se fossem necessárias à sua própria mediação.

No que tange ao cinema, por exemplo, é possível observar algumas dessas correlações compondo integrações semânticas com outros cineastas e escolas do cinema. Polinizada aqui e ali ao longo de seus cento e setenta e três capítulos encontramos influências tais: a) às metáforas visuais ao estilo do cineasta russo Pudovkin (2003) (Figura 5); b) aos enquadramentos repletos de simbologia e uma montagem conflituosa de imagens aos moldes das teorizadas por Eisenstein (2002) (Sequência 1); c) à "estética da fome" (STAM, 2003, p. 114) de Glauber Rocha enfatizando a fisionomia do sertanejo, a literatura de cordel, e o misticismo e sincretismo religioso do povo nordestino (Figuras 6 e 7); d) ao Neo-Realismo de P. Pasolini e M. Antonioni em um "mergulho" à realidade (XAVIER, 2008, p. 78) enaltecendo tanto a paisagem natural do espaço geográfico em que a obra transcorre quanto a solidão e o isolamento do sertanejo diante de uma terra árida (Figura 8); e) e, ainda, à intertextualidade da Nouvelle Vague de Jean-Luc Godard colocando outras obras à paisagem audiovisual da telenovela (Figura 4). 
Figura 5 - Metáfora Visual

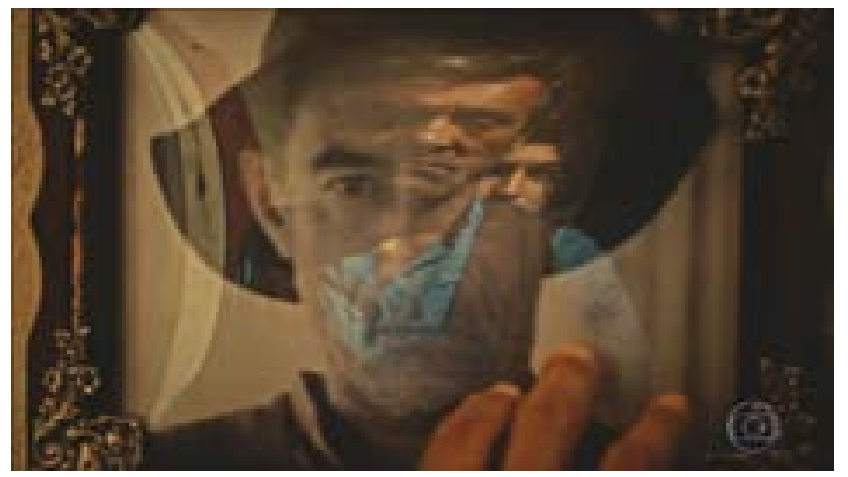

Fonte: Captura feita via Adobe Première.

\section{Sequência de imagens 1}
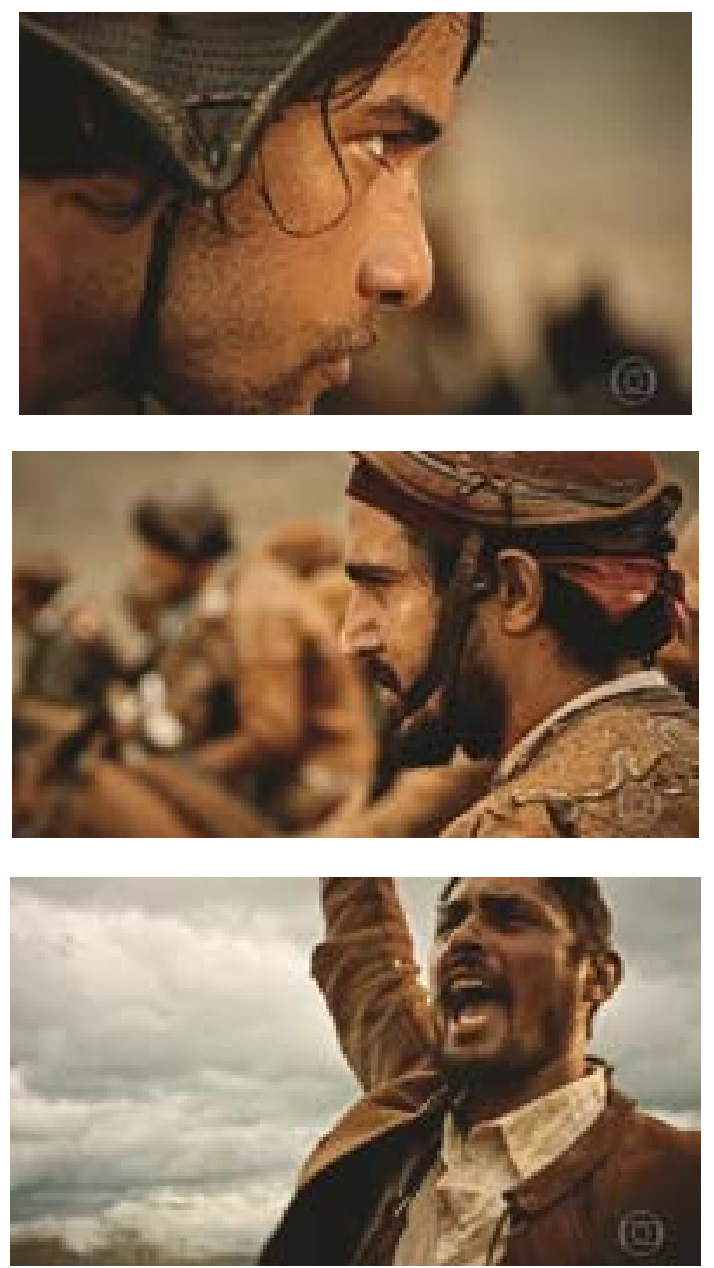

Fonte: Captura feita via Adobe Première. 
Figura 6 - Sertanejo

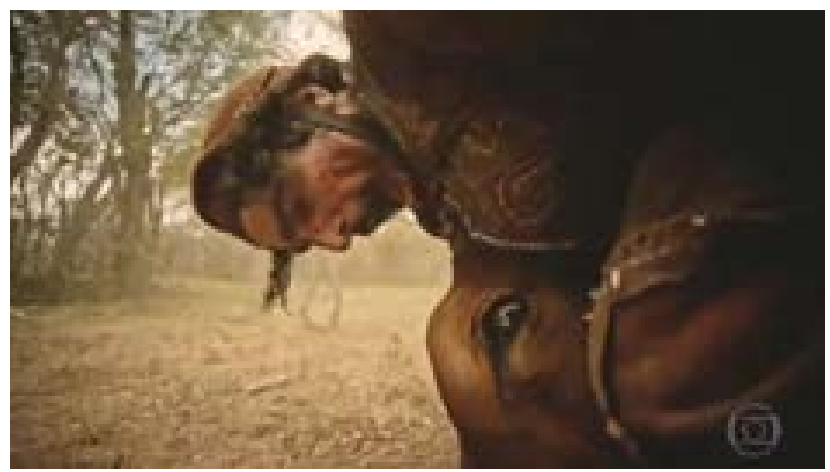

Fonte: Captura feita via Adobe Première.

Figura 7 - Fisionomia

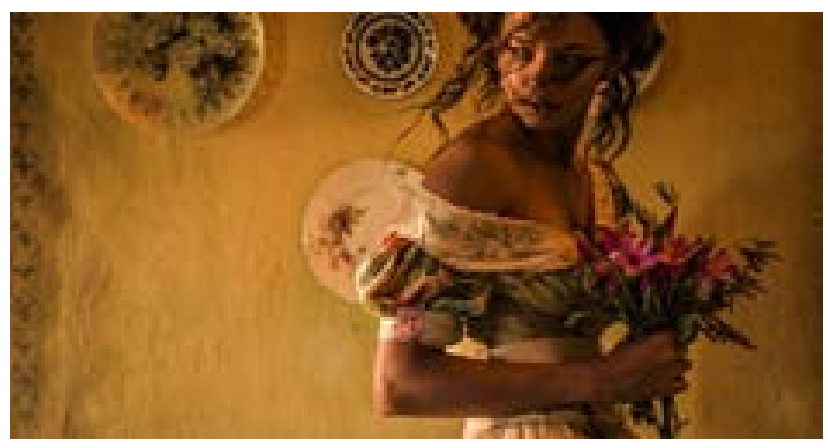

Fonte: purepeople.com.br.

Figura 8 - Vida Sertaneja

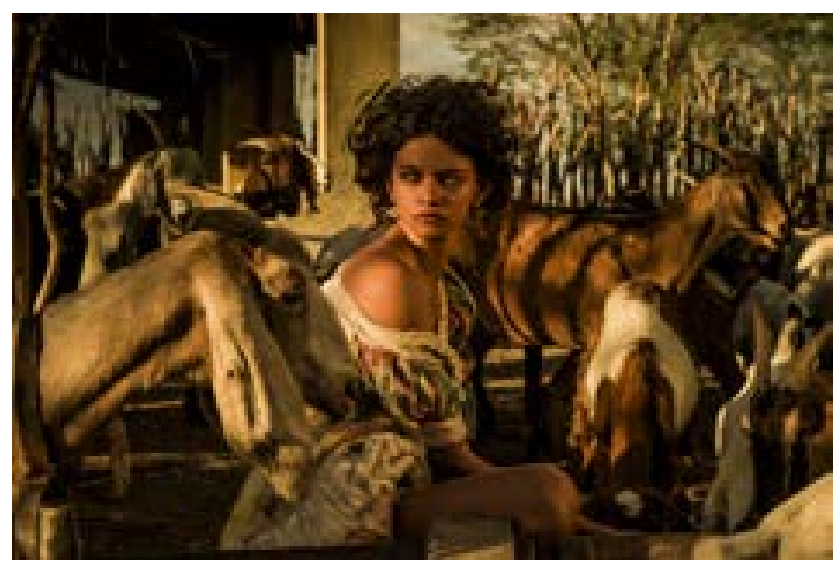

Fonte: notiviasdatv.uol.com.br.

Assim, um personagem, uma trama, uma cena, um capítulo, um evento dramático, serve de palco para as junções, integrações e complementaridades simbólico-culturais diversas entre obras, ritos, figuras folclóricas, movimentos artísticos 
e cineastas. Sobretudo, os conflitos e embates servem de pano de fundo para ali articular uma variabilidade de discursos - políticos, ecológicos, antropológicos, psicológicos - propondo diálogos, soluções e, principalmente, inquietações. Por fim, é pelo contraditório que tal poética encontra seu derradeiro curso forjando vínculos onde havia distâncias e antagonismos. É nesse rincão das inúmeras possibilidades estéticas aliançadas que o sertanejo se torna um herói contemporâneo, pós-moderno. Nele, a liquefação dos gêneros, das artes, das linguagens, das estéticas de uma certa Modernidade Liquida (BAUMAN, 2001) encontra na mestiçagem uma foz.

Mas, como esse movimento é articulado na telenovela?

\section{Sobre Cirandas, Sinergias e Mestiçagens}

É por meio dessa ciranda de integrações semânticas correlacionáveis que Velho Chico perfaz um caminho em torno da mestiçagem, do uno múltiplo. Uma linguagem cabocla, rica exatamente por ser miscigenada e sincrética, como se o ideal estético (AUMONT, 2008), outrora imaterial, tivesse encontrado no mestiço sua verdadeira identidade, ou sua visão de mundo. Tal estética integrativa permeia a direção de arte, a direção de fotografia, o figurino, as encenações, a edição de imagens, a trilha sonora, e a própria direção. Como se aquele universo fosse banhado pelos enraizamentos plurais e diversos da mestiçagem.

Bordwell (2008) explica que existem elementos gerais vinculadas a toda produção audiovisual em termos de convenções de linguagem e de sua produção colaborativa, mas por outro lado existem elementos particulares vinculadas a cultura de quem faz a obra audiovisual. Esta impregna a obra e gera reformulações semânticas de ponta a ponta. Assim, ele esclarece que a manufatura de uma obra audiovisual sempre oferece uma gama de opções estéticas, entretanto, toda escolha depende do ideal a ser perseguido, das convenções a serem trabaIhadas e quais efeitos pretendidos com a obra.

Para dar conta desse processo estético miscigenado - o ideal estético perseguido - é nítido que um compósito de elementos sígnicos são empregados e articulados ao mesmo tempo em instâncias, distâncias e níveis diferenciados se sobrepondo, interpolando e arranjando em fluências variadas e distintas, fornecendo ao telespectador - os efeitos pretendidos - uma rede de signos que fluem em experiências mais complexas em termos de interação com a obra. Fugindo, portanto, do padrão superficial da telenovela - convenções de gênero - onde tudo o que vemos na tela é o todo da história ali narrada. 
Velho Chico acontece e tende para uma direção pré-projetada, ainda que haja alterações ao longo de sua exibição, dado a receptividade ou não com o público, mas faz parte de sua organização semântica entrelaçar todas as esferas sígnicas para uma finalidade: o desenlace da história. Portanto, todas essas camadas de informação fluem, orbitam e transcorrem de maneira sinérgica rumo a um ponto final.

Entretanto, para que este design informacional (opção estética), com suas temporalidades distintas ou flutuações (PRIGOGINE, 2011, p. 70), funcione, demanda uma organização semiótico-sistêmica de tais eventos, narrativas e correlações em rede. $\mathrm{Ou}$, em outros termos, afim de atingir os efeitos pretendidos é preciso observar as opções estéticas adotadas.

No caso de Velho Chico, a "solução" estética foi trabalhar um volume de convergências de sentido distribuídas em pontos focais ou atratores (VIEIRA, 2008). A partir destes pontos focais - eventos dramáticos - é que se articula a maneira como as junções sígnicas diversas - as mestiçagens - vão atuar ao longo da temporalidade das cenas, dos capítulos, das tramas e subtramas.

A questão do tempo surge neste processo, pois é através de inúmeras e distintas temporalidades que as camadas sígnicas são articuladas e dimensionadas, isto é, a sinergia de sentido ecodepende de uma variabilidade signo-temporal. No que tange as suas diferentes temporalidades: existe o tempo macro da telenovela que gira em torno de seis a sete meses, existe a temporalidade da primeira fase e a da segunda, existe a temporalidade das tramas e de seus desdobramentos em subtramas afins, a dos capítulos, ainda a temporalidade das cenas e a temporalidade dos arcos narrativos de cada personagem.

Portanto, tais atratores funcionam como coordenadores de sentido pelo qual todas as cenas, capítulos, personagens e subtramas e tramas fluem, ecodependem e estão internamente correlacionadas. De fato, é devido a estas estruturas atratoras - pontos de virada - que toda a rede de significados distribuídas em camadas são organizadas em termos de difusão de informação.

Na medida em que estas camadas de sentido evoluem, flutuam e ressoam entre si ao longo de diferentes temporalidades e integrações semânticas diversas é que se torna possível correlacionar às informações distribuídas em rede (o efeito pretendido). Tal processo organizacional tem como função, no que tange a formatação de uma poética audiovisual específica, o de manter e regular as informações dispostas nas cenas, nos capítulos, nas tramas, nos arcos narrativos arquitetados, conferindo sempre um retorno - recursividade - a fonte, ao argumento da telenovela e à nucleação: Benedito Ruy Barbosa/Luiz Fernando Carvalho. 
Assim, as referências a outras obras ou ainda a outras linguagens afins, são delineadas em direção a uma finalidade bem concisa: servem para correlacionar, expandir e consubstanciar o próprio argumento/nucleação que sustenta o discurso da telenovela.

Dessa forma, Velho Chico é ao mesmo tempo um ponto de chegada e um ponto de partida para círculo-evoluções sígnicas, isto é, para outros rincões sígnicos, fluindo, desaguando e se ramificando por outras vertentes, criando uma linguagem sinérgica e rizomática, uma ecocomunicação (MORIN, 2005) que para alguns pode ser vista como cacofônica, ou autofágica, mas para outros se transforma em uma gramaticalidade (VIEIRA, 2007), isto é, uma linguagem mestiça própria àquele universo ficcional.

No que tange à sua mediação, Velho Chico oferece níveis distintos de interação, e ao longo desse processo alguns telespectadores permanecem em camadas superficiais, outros percebem e descobrem camadas mais profundas de associações, alusões e correlações aquém do que está à superfície. Porém, é preciso salientar que mobilizar tais camadas de sentido e suas variações e gradações exigem do espectador outra demanda: uma atenção redobrada para que possa se embrenhar em todas as vertentes e nuances criadas, projetadas e desenvolvidas pelos autores e sua equipe. Assim sendo, paga-se, portanto, com uma forte dose de entropia - ruído de comunicação - por tal iniciativa, o que poderia ser traduzido como um risco enorme ao desinteresse, à rejeição e dispersão do telespectador.

\section{Conclusão}

No audiovisual, a busca de um ideal estético é também uma busca de uma autonomia criativa, isto é, de um método mediador de competências semiótico-sistêmicas. É, sobretudo, um rearranjo lógico e ético, uma ação intermitente e autocontrolada, uma constante na busca por um parâmetro poético coeso e coerente.

Tal processo de construção - do fazer artístico - é: (a) uma investigação das potencialidades do signo audiovisual e isso ocorre na medida em que se acumulam experiências com tal linguagem; (b) uma análise crítica na maneira como tal poética pode ser articulada, observando erros e êxitos de tal articulação; (c) e, por último, a adoção de um método de desenvolvimento que clareie, apare e alinhe tal poética em consonância ao ideal estético proposto e eticamente aceito.

Velho Chico é um exemplo notório desse processo, na verdade, uma jornada intelectual que se inicia ainda em 2005, e que talvez já viesse a mais tempo tendo em vista o filme Lavoura Arcaica (2001) nesse processo. Assim, essa propensão estética inicial funciona também como um atrator (VIEIRA, 2007), cujo papel é 
o de estabelecer o eixo gravitacional pelo qual esse ideal vai crescer - recursivamente e retroativamente - em complexidade, portanto iniciando e orientando as círculo-evoluções em outras obras até que se chegue a uma poética, isto é, até que um novo paradigma se sustente como autonomia de discurso.

Entretanto, como Morin alerta (2008a, p. 188): “Não há desenvolvimento linear da complexidade; a complexidade é evidentemente complexa, ou seja, desigual e incerta". Isto quer dizer que cada obra, de Hoje é Dia de Maria até Velho Chico, traz consigo uma complexidade diferente. Dessa forma, dado os desafios de sua realização, cada uma requer estratégias de execução também diferenciadas. É por isso que estabelecer uma poética não quer dizer um engessamento criativo, ao contrário, é, na verdade, um processo de amadurecimento - de aprendizagem - do próprio autor/diretor em conjunto com suas parcerias criativas ao longo desses vários títulos.

Olhando por esse viés é possível afirmar que Luiz Fernando Carvalho vai trilhando um caminho autoral, aos moldes do encontrado no cinema. Por outro lado, tal poética não é cinema, é outra linguagem, híbrida, nem cinema e nem televisão, por certo, mestiça - 'sem raça definida' - mas, sobretudo, com o seu estilo pessoal. E se olharmos para outros diretores como José Luiz Villamarin este não parece ser um caso isolado.

\section{REFERÊNCIAS}

AUMONT, Jacques. O cinema e a encenação. Lisboa: Edições Texto \& Grafia, 2008.

BAUMAN, Zygmunt. Modernidade Líquida. Rio de Janeiro: Jorge Zahar Editor, 2001.

BORDWELL, David. Poetics of Cinema. Nova York: Routledege, 2008.

BRITTOS, Valério; SIMOES, Denis. Cultura popular e sua metamorfose em produto do mercado televisivo. In: DUARTE, Elizabeth CASTRO, Maria Lília (org.). Televisão: entre mercado e a academia. Porto Alegre: Editora Sulina, 2006.

EISENSTEIN, Serguei. A Forma do Filme. Rio de Janeiro: Jorge Zahar Editor, 2002.

MORIN, Edgar. O Método 2: a vida da vida. Porto Alegre: Editora Sulina, 2005.

MORIN, Edgar. O Método 1: a natureza da natureza. Porto Alegre: Editora Sulina, 2008a. MORIN, Edgar. O Método 3: o conhecimento do conhecimento. Porto Alegre: Editora Sulina, 2008b.

PRIGOGINE, Ilya. As Leis do Caos. São Paulo: Editora UNESP, 2002.

PRIGOGINE, Ilya. O Fim das Certezas. São Paulo, Editora da UNESP, 2011. 
PUDOVKIN, Vsevolod. Métodos de tratamento do material (Montagem estrutural). In: XAVIER, Ismail (org.). A Experiência do Cinema. 3.ed. Rio de Janeiro: Edições Graal: Embrafilmes, 2003.

SANTOS, Marcelo Moreira. Poética do Cinema: sobre complementariedade, direção e método no processo de criação. Revista Científica/FAP, Curitiba, v. 12, p. 213-229, jan./jun., 2015.

STAM, Robert. Introdução à Teoria do Cinema. Campinas: Editora Papirus, 2003.

VIEIRA, Jorge de Albuquerque. Ciência - Formas de Conhecimento: Arte e Ciência uma visão a partir da complexidade. Fortaleza: Gráfica e Editora, 2007.

VIEIRA, Jorge de Albuquerque. Ontologia - Formas de Conhecimento: Arte e Ciência uma visão a partir da complexidade. Fortaleza: Expressão Gráfica e Editora, 2008.

XAVIER, Ismail. O discurso cinematográfico. São Paulo: Editora Paz e Terra, $4^{\circ}$ edição, 2008.

\section{Figuras}

Figura 1 [Imaginário Popular]. Disponível em: http://gshow.globo.com/Bastidores/ noticia/2016/06/lucy-alves-diz-como-vai-conciliar-gravacoes-de-velho-chico-com-festas-juninas-nao-abro-mao.html. Acesso em: 21 mar. 2019.

Figura 2 [Oratórios]. Disponível em: https://extra.globo.com/tv-e-lazer/telinha/larissa-goes-sera-luzia-na-fase-jovem-da-personagem-em-velho-chico-18620429.html. Acesso em: 21 mar. 2019.

Figura 3 [Corpo Fechado]. Disponível em: https://tvefamosos.uol.com.br/blog/mauriciostycer/2016/04/30/nao-esta-entendendo-velho-chico-leitor-noveleiro-desenha-pra-voce/. Acesso em: 21 mar. 2019.

Figura 4 [Dom Quixote]. Disponível em: https://noticiasdatv.uol.com.br/noticia/opiniao/ marcada-por-tragedia-velho-chico-termina-melancolica-e-sombria--12719. Acesso em: 21 mar. 2019.

Figura 5 [Metáfora visual]. Disponível em: https://www.youtube.com/watch?v=RHePOETDQKk\&t=3s. Acesso em: 21 mar. 2019.

Figura 6 [Sertanejo]. Disponível em: https://www.youtube.com/watch?v=-jKofZoeLS8\&t=17s. Acesso em: 21 mar. 2019.

Sequências de Imagens 1. Disponível em: https://www.youtube.com/watch?v=-jKofZoeLS8\&t=17s. Acesso em: 21 mar. 2019. 
Figura 7 [Fisionomia] Disponível em: https://www.purepeople.com.br/midia/leonor-marina-nery-morre-ao-dar-a-luz m1397847. Acesso em: 21 mar. 2019.

Figura 8 [Vida Sertaneja]. Disponível em: https://noticiasdatv.uol.com.br/noticia/ novelas/velho-chico-leonor-morre-apos-dar-luz-filho-de-afranio-10745. Acesso em: 21 mar. 2019.

\section{Dados do autor:}

Marcelo Moreira Santos - e-mail: mcloms@gmail.com

Graduado em Comunicação Social - Rádio e TV pela Universidade Católica Dom Bosco - MS, Especialista em Comunicação Audiovisual pela PUC-PR, Mestre e Doutor em Comunicação e Semiótica pela PUC-SP, Pós-Doutor em Comunicação, Cultura e Arte pela Universidade do Algarve, Portugal, atuando principalmente nos seguintes temas: Poética do Cinema, Autoria Colaborativa no Cinema, Montagem, Cinematografia, Interpretação Fílmica e Ecossistemas Transmidiáticos. É membro pesquisador do Centro Internacional de Estudos Peircianos - CIEP desde 2007.

\section{Endereço do autor:}

Faculdade Estácio de Sá - Polo Campo Grande - Av. Fernando Corrêa da Costa, 1800 - Vila Rosa Pires - Campo Grande (MS) - Brasil 